\title{
A MOEDA DO TEMPO E OUTROS POEMAS
}

Ida ALVES ${ }^{87}$

CRUZ, Gastão. A moeda do tempo e outros poemas. Organização de Jorge Fernandes da Silveira. Rio de Janeiro: Língua Geral, 2009 (Coleção Língua Real). 198 p.

$\mathrm{Na}$ última década, na esteira do primeiro prêmio Nobel - Literatura - recebido por um escritor de língua portuguesa, José Saramago, em 1998, aumentou o interesse editorial brasileiro pela publicação de autores portugueses contemporâneos, ultrapassando-se a figura pessoana tão dominante. Porém, essa literatura continua, de certa forma, estrangeira no Brasil. Excetuando o espaço acadêmico dos muitos cursos de Letras espalhados pelo país, com disciplinas de literatura portuguesa, pouco circula entre nós a produção atual do outro lado do Atlântico. Em relação às obras de poesia, a situação é ainda mais grave, se consideramos que a quantidade de leitores desse tipo de produção já é normalmente menor, mesmo para os nossos poetas de cada dia.

É fato que, felizmente, surgem, aqui e ali, algumas ações editoriais em busca de interromper esse curto-circuito e, com isso, temos atualmente a possibilidade de encontrar algumas boas edições brasileiras de poetas portugueses. É o que vem fazendo a Escrituras, em São Paulo, com a coleção Ponte Velha, e, no Rio de Janeiro, a 7Letras, Oficina Raquel e Língua Geral. São projetos em convênio com o Ministério da Cultura de Portugal e seu Instituto do Livro e das Bibliotecas, além de apoios acadêmicos brasileiros vindos do CNPq e CAPES. Mas são, sobretudo, o resultado do trabalho contínuo de divulgadores brasileiros da poesia portuguesa. É o caso desta antologia da poesia de Gastão Cruz, com organização de Jorge Fernandes da Silveira, professor titular de literatura portuguesa da Universidade Federal do Rio de Janeiro, e nome referencial nacional e internacionalmente nos estudos críticos dessa produção lírica.

\footnotetext{
${ }^{87}$ Professora de literatura portuguesa e Coordenadora do Núcleo de Estudos de Literatura Portuguesa e Africana (NEPA), Instituto de Letras, Universidade Federal Fluminense, UFF, Niterói, RJ, Brasil idafalves@gmail.com
} 
Trata-se de uma edição bem cuidada, com revisão do próprio poeta, pela primeira vez publicado no Brasil, que reúne poemas representativos dos seus diversos livros, percorrendo o espaço de quarenta e nove anos de trabalho poético, ou seja, desde A morte percutiva, plaquete publicada em 1961, junto com mais quatro plaquetes de companheiros universitários: Fiama Hasse Pais Brandão, Luiza Neto Jorge, Maria Teresa Horta e Casimiro de Brito, até A moeda do tempo, de 2006. Na antologia, o ordenamento dos poemas se faz da obra mais recente até a de 1961, provando a fidelidade do poeta aos seus temas de eleição e a sua extrema atenção ao fazer poético.

Com apresentação esclarecedora ("Apresentar Gastão ou o presente da poesia”) de Luis Maffei, poeta carioca e também professor de literatura portuguesa na Universidade Federal Fluminense, e um posfácio "à maneira de leitura comentada, em voz alta" assinado pelo organizador, Jorge Fernandes da Silveira, a edição em preto (a cor plena das páginas separadoras dos diversos livros e predominante na capa e contracapa), dá-nos a oportunidade de conhecer uma das vozes mais fortes e reconhecidas da poesia moderna e contemporânea de Portugal.

Seus poemas depurados, rigorosos no domínio do verso e intensos no trabalho da memória e da escrita, são experiências de tempo no que tem de doloroso mas também de reencontro de histórias íntimas e irrepetíveis. “..., assim o poeta / com o buril inscreve na deserta / chapa do mundo não interpretado / o sentido precário de o olhar." (p.38). A moeda do tempo que transita por muitas mãos, rolando pelos versos e, por vezes, indo parar em cantos inesperados da vida, é a metáfora bem-vinda para o poema. "Distraí-me e já tu ali não estavas / vendeste ao tempo a glória do início / e na mão recebeste a moeda fria / com que o tempo pagou a tua entrada", avisa o poema que abre a antologia.

O poeta Gastão Cruz, também crítico da literatura e tradutor, é, antes de tudo, um leitor apaixonado da poesia de tempos diversos, atento aos poetas da sua língua, mas também conhecedor exigente de ingleses, americanos, espanhóis, franceses e outros, os clássicos, os perenes. Ouvido acurado, e fiel defensor de que o poema é materialidade sonora, física, que penetra corpos (penso em todo o trabalho que realizou durante anos em prol de audições de poesia em colégios e escolas portugueses, além da direção de teatro que muito exerceu), sua poesia busca a palavra exata, a construção da imagem isenta de excessos que possam desviar o leitor do verso e do poema. 
Autor de uma obra que em breve completará cinquenta anos de construção, não se pode deixar de notar que sua escrita poética acompanhou momentos muito diferentes do contexto português aos quais respondeu sempre com vitalidade, força e sensibilidade lírica. No início, na década de 60, sua poesia enfrentou demandas de um tempo de opressão e silenciamento imposto pelo salazarismo, revelando um corpo verbal dinâmico ainda que ferido e torturado. Nesse momento, com atenção linguística acentuada, podemos dizer que sua escrita poética explorava a potência do significante e provocava as rasuras do discurso lírico por meio das quais era possível fazer escoar a vontade de liberdade e de criação de uma outra realidade. Após 74, com a Revolução dos Cravos, e outros contextos de produção, o poeta voltou-se para uma subjetividade mais exposta e um encontro mais afetivo com seu tempo interior e com o tempo do mundo. Nessa perspectiva, o tema da morte que sempre esteve presente em sua poética deslocou-se da experiência do outro (corpo ferido) para um assumir mais evidente de sua própria experiência de finitude, a partir da perda escrita no corpo do sujeito lírico pela passagem irrevogável do tempo: "Mora no corpo ainda a errante / linguagem? / A língua do abismo / só os olhos a falam [...]”' (p.65). Memória e morte são assim questões fundamentais que marcam a sua escrita e são perseguidas nessa antologia. É o que se vê no poema "Em tempo alheio", com a epígrafe "Peço desculpa de ser o sobrevivente", verso de Drummond: "Demasiados mortos para a / minha memória / O dia está aí um projector nos rostos / que repetem / cenas, deslocando-se entre os móveis / polidos pelos anos e as árvores, com falas retardadas / Não há quem sobreviva a ninguém no cenário / são somente aparências o que está / e o que falta, / todos em cada um, / enquanto ausentes o habitam como casa / em tempo alheio / Deixastes toda a esperança vós que entrastes / na memória" (p.63).

Em outro momento, cheguei a escrever que a escrita de Gastão Cruz era cruel (“A poética de Gastão Cruz é intrinsecamente uma poética do corpo tenso e se estende ao leitor de forma cruel, ou seja, sem omissão, sem comiseração, sem ilusão.”) e não vou desistir desse adjetivo agora. Cruel por sua clareza, por sua evidência existencial, por sua exigência formal e afetiva, por sua certeza de que a poesia que vale a pena não abre mão de valores estéticos e éticos, não se molda nem se acomoda. Palavra justa e justa memória de tradições poéticas. Cruel aí como cruel é a faca de João Cabral de Melo Neto ou o silêncio de Graciliano Ramos. A não conivência com o falso, o 
anedótico, o banal que, por vezes, assume a máscara simpática e risonha de ser poesia. De outra matéria são feitos esses poemas: palavra forte, segura e não moldável. Não à toa, a boa escolha da capa dessa antologia: pedras negras, vulcânicas poderiam ser, apontando num mar de bruma. Pedra é uma boa imagem para seus poemas: formas carregadas de sentidos, em potência de energia, mas superficialmente concentradas em si, imóveis e moventes na página.

Um livro de poesia não se explica, vivencia-se pelo olhar, pela leitura em silêncio ou na sedução da palavra dita em voz alta. Assim requer a escrita de Gastão Cruz, que não se oferece facilmente ao leitor distraído. No entanto, para os leitores realmente leitores, conhecer a poesia desse poeta português de hoje é poder imergir no conhecimento da poesia de sempre, dos grandes clássicos e dos grandes já seus contemporâneos, demonstrando que a poesia é um diálogo permanente de vozes, de emoções e de olhares sobre o mundo e sobre as coisas. "[...] // Aprendi a clareza das imagens fictícias / recolhidas na luz do corpo nu e vivo / entre os golpes orais, errante, desferidos" (p. 125). 